\title{
Cultura, natureza e história na invenção alencariana de uma identidade da nação brasileira
}

Valdeci Rezende Borges

UFG

\section{RESUMO}

Este artigo aborda, primeiramente, as relações estabelecidas entre cultura, natureza, sociedade, história e literatura no ensaio crítico Benção paterna, de José de Alencar, no qual se expressa a preocupação com a edificação de uma literatura brasileira, com "cor local" e uma identidade nacional. Em seguida, focam-se as descrições da natureza fluminense no romance Sonhos d'ouro, observando as formas culturais de interação dos indivíduos com os aspectos físico-naturais e as apreciações sobre eles inseridas num processo de produção de um imaginário formador de uma identidade da nação e da cidade, no qual se põem em relevo suas singularidades, belezas e monumentalidade.

Palavras-chave: Cultura e natureza; História e literatura; Imaginário e identidade nacional; José de Alencar.

\section{ABSTRACT}

At first, this article deals with the relationship established between culture, nature, society, history and literature in the critical essay Benção paterna, by José de Alencar. The essay express his concerns about the edification of a Brazilian literature, with "local color" and a national identity. Next it focuses the descriptions of the nature from the region surrounding the city of Rio de Janeiro in the novel Sonhos d'ouro, noticing the cultural ways of individual's interaction with the physical and natural aspects and the appreciations about them in the production process of an imaginary which is responsible for the nation and city's identity, in which are pointed out its singularities, beauties and monumentallies.

Keywords: Culture and nature; History and literature; Imaginary and national identity; José de Alencar. 
José de Alencar, ao longo de sua carreira de escritor, produziu uma reflexão teórica e metodológica sistemática voltada para a busca de construir e consolidar um paradigma para a escrita de sua obra, a qual, ao mesmo tempo, elaborava. Procurou uma forma narrativa "moderna" e que fosse adequada para formatar a literatura nacional, contribuindo para a edificação do romance brasileiro e da invenção de uma identidade para a jovem nação. Tais proposições, que entrelaçam questões como a relação entre cultura, sociedade e natureza, entre história e literatura, estão presentes em vários de seus ensaios críticos, uns em forma de cartas e posfácios, outros de pós-escritos e prefácios, assim como em seus romances, que são a formalização dessas propostas.

Este artigo tem como o objetivo, primeiramente, abordar as relações tecidas entre esse conjunto de elementos, qual sejam, natureza, cultura, sociedade e história, com base em Benção paterna. Em seguida, busca-se tratar, por meio das descrições da natureza fluminense, no romance Sonhos d'ouro, das práticas culturais de interação dos indivíduos com ela e da edificação de um imaginário social formador de uma identidade do lugar e da nação, dado num processo relacional com outras sociedades e culturas.

Para Alencar, a "literatura militante" deveria apreender "a alma brasileira" num processo cultural de oposição ao "espírito de colonização literária", que os "literatos de rabicho", portugueses, tentavam impor aos escritores e leitores no Brasil, sendo "missão" dos escritores, na "formação de uma nacionalidade", agir como "operários incumbidos de polir o talhe e as feições da individualidade" que se iam "esboçando no viver do povo". Na tarefa de edificar uma literatura que abarcasse a realidade nacional, vista como "alma da pátria”, ele, em Benção paterna, de 1872, estabeleceu uma periodização para a literatura brasileira, partindo de sua própria produção, abrangendo a história, os povos constituintes da sociedade e da cultura brasileiras e os vários pontos do chão pátrio com suas especificidades naturais. Deslocou-se no tempo e no espaço para construir um grande painel da diversidade cultural e natural brasileira. ${ }^{1}$

Referindo-se à reverência que, sobretudo, os críticos portugueses exigiam dos escritores brasileiros no emprego do velho português quinhentista, Alencar reafirmou o caráter nacional de sua literatura, relacionando-a com a história da sociedade brasileira, distinguindo três fases que a fundamentavam. Era momento de avaliação, de balanço e de sistematização, de sua proposta teórica e prática literária, com um olhar interpretativo, retrospectivo e prospectivo, sobre sua produção, que, significativamente, assinou por Sênio. ${ }^{2}$ Via 
o trabalho do romancista como de um missionário, esforçado "por abrir caminho ao futuro", lutando para criar uma literatura num contexto cultural desfavorável devido à crítica, que lhe imputava observações de hostilidade ou a indiferença, sempre com o intuito de desqualificá-lo, além da existência de um círculo restrito de leitores. ${ }^{3}$

Defendeu a historicidade da produção literária enfatizando a interligação do romance com seu tempo e meio cultural, ao falar da leveza que requeria a nova forma narrativa adequada à modernidade e a sua rapidez, representada pela imagem da locomotiva e do vapor. Afirmava que, na nova sociedade, não havia espaço para grande pretensão literária e que seu romance era "o livro de seu tempo, o próprio filho deste século enxacoco e mazorral, que tudo aferventa a vapor, seja poesia, arte, ou ciência".

Em relação à dita "cor local", aspecto valorizado na produção e apreciação de uma obra literária, a busca "do matiz brasileiro", "daquele sabor de terra”, atrelado ao ensejo da produção de uma literatura nacional diversa da portuguesa, original pela mescla cultural e contato com a natureza, comentava:

Lá uns gênios em Portugal ... tomaram a si decidir o pleito, e decretaram que não temos, nem podemos ter literatura brasileira ... Este grande império é uma nação oca; não tem poesia nativa, nem perfume seu; há de contentar-se com a manjerona, apesar de ali estarem recendendo na balça a baunilha, o cacto e o sassafrás ... Os oráculos de cá, esses querem que tenhamos uma literatura nossa; mas é aquela que existia em Portugal antes da descoberta do Brasil. Nosso português deve ser ainda mais cerrado, do que usam atualmente nossos irmãos de além-mar ... para dar-lhe o aspecto de uma mata virgem. ${ }^{5}$

Ao periodizar sua obra em três fases, atrelando-as ao espaço natural e ao movimento histórico, cultural e político brasileiro, considerou que a fase primitiva, chamada "aborígene", tratava das lendas e mitos da terra selvagem e conquistada, sendo representada por Iracema e, posteriormente, Ubirajara. O período "histórico", representando "o consórcio do povo invasor com a terra americana", foi abordado em O Guarani, As minas de prata e depois Guerra dos Mascates. Já a fase vista como da "infância de nossa literatura, começada com a independência política" e ainda não terminada naquele momento, era de formação do "verdadeiro gosto nacional" e tinha uma proposta ideológica de "fazer calar as pretensões tão acesas de nos recolonizarem pela alma e pelo coração, já que não o podiam pelo braço”. ${ }^{6}$

Ressaltando essa perspectiva política de formação de uma literatura na- 
cional para consolidar a independência, considerou existir, no último período, dois momentos distintos. Um, em espaços e recantos rurais, em que "não se propagava com rapidez a luz da civilização, que de repente cambiava a cor local", e outro, no espaço urbano, focado na Corte, onde tudo se transformava com ligeireza. No primeiro, encontrava a cor brasileira "ainda em sua pureza original, sem mescla", captando "o viver singelo de nossos pais, tradições, costumes e linguagem, com um sainete todo brasileiro", conforme expresso em O tronco do ipê, Til, O gaúcho e, posteriormente, em O sertanejo. Já no segundo, a sociedade tinha "fisionomia indecisa, vaga e múltipla, tão natural à idade da adolescência”, pois "efeito da transição que se opera; e também do amálgama de elementos diversos”, como observado em Lucíola, Senhora, Diva, Sonhos d'ouro e, depois, Encarnação.?

Sobre esses últimos romances, urbanos, ponderava que seu conteúdo advinha de um processo de "importação contínua de idéias e costumes estranhos", que dia por dia traziam todos os povos do mundo, os quais deviam "formar o amálgama indigesto", de que deveria "sair mais tarde uma individualidade robusta”. Múltiplos "traços de várias nacionalidades adventícias" iam "diluindo-se para infundir-se n'alma da pátria adotiva, e formar a nova e grande nacionalidade brasileira", forjada numa "luta entre o espírito conterrâneo e a invasão estrangeira".

Ao defender o enraizamento da produção literária na natureza e no meio cultural, como forma de edificar um tipo de nacionalidade literária, ponderava que a postura da crítica, de tachar "estes livros de confeição estrangeira", advinha de "não conhecer a fisionomia da sociedade fluminense" que estava "a faceirar-se pelas salas e ruas com atavios parisienses" e falava a língua do progresso, arrepiada de termos franceses, ingleses, italianos e alemães. Para ele, se a literatura tinha de tirar a fotografia da sociedade, ela flagrava tais feições num processo de aclimatação da produção literária, de formação da tradição e da nacionalidade, que requeria os traços de individualidade do povo em seus usos e a ação dos literatos de registrá-los, de empregá-los como matéria-prima e limá-los para erigir "os monumentos literários da pátria”.

Deste modo, colocando-se na missão de erguer a literatura como um monumento cultural da sociedade e da nação, salientou que os críticos nunca alcançariam que ele escrevesse nesse Brasil coisa que parecesse "vinda em conserva lá da outra banda, como a fruta que mandavam em lata", pois, por sua natureza e cultura, "O povo que chupa o caju, a manga, o cambucá e a jabuticaba, não podia falar uma língua com igual pronúncia e o mesmo espírito do povo que sorve o figo, a pêra, o damasco e a nêspera". ${ }^{10}$ 
Assim, Alencar acusado de pouco vernáculo pelos defensores do purismo lusitano, pois seus textos estariam inçados de americanismos ou brasileirismos, termos pejorativos que indicavam as particularidades lexicais e gramaticais da língua portuguesa falada pelo povo brasileiro, preconizava o uso de um português modificado pela natureza e cultura aqui existentes, por ver a identidade da língua que se fala correlata à do homem que o faz, não se tratando, pois, do português corrente em Portugal. Com essa concepção do povo e da língua brasileiros, não admitia que a literatura nacional, que é "a alma da pátria”, reproduzisse os cânones lingüísticos portugueses e deveria, assim, incorporar a variante lingüística que se falava no país independente. Portanto, ao perceber a historicidade das formas de expressão, que apresentam exigências constituídas social e culturalmente, atacou o purismo vernacular português, a caturrice gramatical e o respeito indulgente à estética classicista, e procurou explorar novas formas que requeriam uma revisão dos princípios e pontos de vista sobre a língua portuguesa no Brasil. ${ }^{11}$

\section{“UMA RAINHA ALTIVA EM SEU TRONO” NATURAL DE "MAGNÍFICAS PAISAGENS"}

Sonhos d'ouro, que teve Bênção paterna como prefácio, é um dos romances em que Alencar empregou as propostas teóricas antes apresentadas. No caminho da construção da identidade da nação brasileira, o romance vincula cultura e natureza, experiências socioculturais e aspectos naturais, elementos nativos e estrangeiros, tendo lugar na trama aquela sociedade da Corte mais receptiva às idéias e costumes advindos de outras nações e culturas. Sociedade permeada pela presença dos elementos físico-naturais do lugar e de práticas culturais várias, como aquelas advindas do exterior, que eram pulverizadas com rapidez e modificavam a "cor local".

O enredo de Sonhos d'ouro gira ao redor das figuras centrais de Guida e Ricardo. Ela é moça bonita, rica, educada à inglesa, versada em salões, mimada e adulada, tendo todos seus caprichos realizados, pois filha de um milionário, banqueiro. Ele, um jovem bacharel, pobre e de caráter nobre, vindo da província de São Paulo para trabalhar, obter recursos para assegurar o futuro de sua família numerosa e conseguir vinte contos de réis para saldar, num banco, a hipoteca da chácara na qual moravam seus familiares. A história começa com um passeio pela Tijuca, no tropical verão fluminense, quando os dois personagens se encontram. 
Das páginas do Diário do Rio, no qual Alencar fora redator-chefe, vieram censuras ao livro, como previa em seu prefácio, que apontavam seu caráter estrangeiro, suscitando que o autor viesse a público rebater tais questões no texto Os sonhos d'ouro. Para o crítico, não identificado, Guida e Ricardo eram "personagens estrangeiros" e não "tipos naturais da nossa sociedade". Isso levou o romancista a declarar que "Desconhece a vida fluminense quem negar a existência do que se chama entre nós 'a alta sociedade', embora sem o esplendor do grand monde em Paris e da high life em Londres". Conclamava ainda que o crítico "chegasse à janela da sua tipografia em um dia de festa" para ver "passar-lhe diante dos olhos não uma, senão muitas moças mais caprichosas e aristocráticas do que Guida". ${ }^{12}$

Alencar invocava o leitor crítico a ater-se à observação da cidade e da sociedade para encontrar "o traço brasileiro", que estava "aí se revelando", na busca de mostrar que Guida resultava desse exercício de olhar a vida mundana da alta sociedade fluminense, sendo personagem verossímil e tendo atitudes pertinentes a ela. O mesmo ocorria com Ricardo e sua postura de "homem prático, preocupado dos interesses positivos da vida", lutando "com corajosa tenacidade contra as dificuldades do tirocínio". Acreditava que a "pecha de estrangeirismo" era indevida também ao dar a "entender que destoavam de nossa 'sociedade franca e democrática", como se a sociedade representada não possuísse essas características, ainda que dois "moços pobres e desconhecidos” fossem convidados a jantar em casa rica logo depois de rápido conhecimento e "onde a fidalguia é representada por titulares de carregação, como um barão que foi tropeiro, um visconde que foi belchior, e um conselheiro que tem casa de consignações". Reafirmava que os personagens eram produtos do meio cultural e salientava que "nem Guida, nem Ricardo são tipos, mas caracteres formados pelas nossas condições sociais, idiossincrasias, como outras que aí estão se reproduzindo ao infinito, sob a influência de um concurso qualquer de circunstâncias". ${ }^{13}$

Esses personagens, em tal contexto sócio-cultural, inserem-se numa trama marcada por "episódios de uma história do ouro", como as maneiras de enriquecimento e aquisição dos títulos de nobreza, as relações tecidas pelo dinheiro, como as de casamento e de amizade, o desejo do lucro a devastar a natureza, as disputas econômicas e a atividade política, a diferença de condição social e a consciência como obstáculo a uma relação amorosa. Mas não é só; pelas descrições da natureza fluminense, Alencar contribuía para a edificação de um imaginário formador da identidade da cidade, do lugar e da nação, revelando suas singularidades, belezas e monumentalidade, ao dar pros- 
seguimento ao expediente iniciado no seu primeiro romance urbano, Cinco minutos. Neste, a natureza, com seus elementos, matas, montanhas, mar, cores, luminosidade, dá o tom da cor local revelada na descrição de duas viagens realizadas pelo personagem narrador, à Tijuca e a Petrópolis. A narrativa faz referências a uma história natural e produz imagens da paisagem que confere identidade à região e possui poder espiritual e sanitário, de cura. ${ }^{14}$

A natureza citadina e de seu arrabalde foi incorporada ainda ao enredo de vários outros romances urbanos do escritor, merecendo menção o perfil de mulher Diva. Aí, o ambiente natural, conforme as idéias de Rousseau, presentes em Emílio e Júlia ou a Nova Heloísa, tem papel decisivo na formação do indivíduo, no caso Emília. Seu caráter singular, de mulher transgressora, forte e autônoma, abre caminho à constituição de uma mulher moderna, resultando do entrecruzamento dos elementos naturais e culturais. Ao mostrar seu mergulho no mundo natural e seu envolvimento visceral com a natureza, o narrador descreve e elogia a paisagem, além de criticar a sociedade, sua cultura opressora e o progresso destruidor.

No entanto, aqui, neste artigo, a intenção é ater-se a Sonhos d'ouro, na busca de tratar, primeiramente, dos aspectos naturais e de perceber como Alencar concebeu-os e que práticas, valores e idéias aparecem a eles relacionados, contribuindo para a construção do imaginário sobre a natureza fluminense. Natureza, como objeto acerca do qual se edificam representações, veicula visões de mundo e contribui, com suas imagens, para compor o repertório cultural brasileiro, estando relacionada, assim, com a política. Os aspectos naturais davam singularidade à cidade, à localidade, à região e, logo, ao país, daí buscar identificar um ser distinto e original. Ao descrevê-los, neles inspirar-se e inseri-los num processo relacional com aqueles de outros países, o escritor construía, afirmava positivamente a particularidade da cidade e da nação. ${ }^{15}$

SOB O SOL DE VERÃo DA TIJUCA: NATUREZA FLUMINENSE, COR LOCAL E A EDIFICAÇÃO DA IMAGEM DE UMA CIDADE MARAVILHOSA

O livro, que se abre anunciando as belezas da natureza fluminense com a frase "O sol ardente de fevereiro dourava as lindas serranias da Tijuca", possui, em grande parte, esse espaço natural como cenário no qual se desenrola a trama. Em passagens que se desenvolvem ao redor de passeios dos personagens pelos vários pontos de visitação da montanha, ou naquelas que ocorrem 
na residência de veraneio de Guida, a Tijuca ocupa lugar privilegiado no transcorrer do romance. Dos 34 capítulos, pelo menos 22 deles, acrescidos ao do pós-escrito, possuem esse espaço como ambiente das cenas. Apenas do capítulo XXIII para frente, o palacete à Praia de Botafogo toma a primazia. Ao mundo ordenado e conquistado pelo dinheiro e cálculos de lucros, a natureza da Tijuca é uma área mais afastada e reservada, de certo modo, um refúgio do espírito mercantilista que perpassa esses sonhos d'ouro. ${ }^{16}$

Nos capítulos marcados pela presença da montanha, natureza, cultura e sociedade interagem ao serem conciliadas nas práticas dos indivíduos. No entanto, embora se apresentem de modo articulado, a sociedade, com suas características capitalistas, teve ressaltadas suas dimensões negativas e maléficas. A flor que brotava num espaço-tempo próprio e o simbolizava, como forma de existência pré-capitalista, foi descrita como originária de uma "natureza lerda, que ainda cria pelo antigo sistema, com o sol e a chuva". Mas ela remete, por sua cor, àquilo que a sociedade moderna, capitalista, "que tudo aferventa a vapor" e "tudo reduz a uma pequena operação química”, elegeu como símbolo para tudo mediar o ouro, o dinheiro. A natureza representa um tempo singular, sendo marcada pelo vagar; nela, a "pequena flor silvestre" do arbusto das matas da Tijuca tinha botões que despontavam "em dezembro, por muito tempo se conservando estacionários; sem crescimento aparente" e "só dois ou três meses depois, em fevereiro e março, que as gemas d'ouro" se elevavam como aljôfares e desabrochavam para murchar em um dia. ${ }^{17}$

Já a sociedade era lugar do corrido e da corrida ao ouro, em que de porqueiro, enriquecendo-se, torna-se banqueiro e Comendador; de tocador de tropa de muares, Barão; de comerciante de objetos velhos e usados, Visconde... Nela, as flores e animais, como as aves, eram associados aos nascimentos de estufa, resultados de "operação química, por meio da qual suprime-se o tempo, e obriga-se a criação a pular, como qualquer acrobata”. Alencar escolheu, nas matas da Tijuca, a flor cor de ouro, que submetia seu ciclo de floração pacientemente ao ritmo lento da natureza, para simbolizar um estado contrastante e ambivalente de coisas. Fê-lo após anunciar, no prefácio, a busca de uma nacionalidade original sinalizada no perfume das ervas recendentes vindas da cerca viva, do canteiro ou jardim das casas, como a baunilha, o cacto e o sassafrás; depois de falar da linguagem de um povo que tinha língua que chupava frutas como caju, manga, cambucá e jabuticaba, vindas de floradas cheirosas e possuindo sabores tropicais; de remeter às "flores de estufa" e criticar, a seguir, o artificialismo da sociedade norte americana, "que inventou uma máquina de chocar ovos", a ela contrapondo, com pilhéria, uma brasileira, a Tijuca e suas capoeiras, que sobrepunham aquela engenhoca com 
resultados quantitativos e qualitativos, com a criação de muitos galos, galinhas e frangos. ${ }^{18}$

Tecido um rápido painel descritivo da paisagem das "lindas serranias da Tijuca", Ricardo, nele inserido, foi apresentado ao leitor. Nesse espaço, banhado pelo dourado do sol do verão tropical, numa "formosa manhã" de céu arreado "do mais puro azul", de "verde relva e da folhagem" coberta de orvalho, que cambiava "aos toques da luz" por entre "flocos de névoa" restantes "da cerração da noite" e que "cingiam ainda os píncaros mais altos da montanha", flutuantes "ao sopro da brisa", o moço apareceu como "um passeador solitário", que "seguia a pé e distraidamente por um dos muitos caminhos que se cruzavam em várias direções pela encosta ocidental da montanha”. Será ele, aqui, personagem com perfil de viajante de uma expedição, nosso guia por tal território, posto que suas andanças são verdadeiras diligências de conhecimento, sendo conhecedor dos trilhos batidos, do mapa do lugar, e rumando ainda por dentro do mato entre a ramagem do arvoredo. Assim, mostrava e descrevia as belezas, peculiaridades e ocupação dada à montanha, como a Vista Chinesa, lugar de piqueniques, o Hotel do Jourdain e o Hotel do Sr. Bennett, dentre outros. ${ }^{19}$

Ricardo encobria-se por detrás da folhagem das árvores e seu olhar desvelava a natureza do lugar; seu pensamento vagava de uma a outra espécie inventariando essa vegetação, de uma moita a outra, "do ramo ao tronco, da folha à raiz" até que alguma coisa chamasse sua atenção como a flor dourada que passa a ser descrita minuciosamente pelo narrador. Era pequena, tinha "linda corola" e "forma de um junquilho", uma "bela cor de ouro, e aveludada como a açucena"; botões "como pequenas contas de ouro", que não cresciam, nem se abriam ao mesmo tempo, vindo solitários, um depois do outro. O rapaz não sabia "o nome do arbusto, nem mesmo se já foi batizado pela ciência", reportando-se às expedições científicas custeadas pelo governo para observar, inventariar, descrever, classificar, rotular e mostrar a monumentalidade da natureza brasileira. Indicando o entrecruzamento dos campos culturais, fazendo trocadilho, remeteu-se a dois desses estudiosos, chamando-os freires, por tratar primeiro, do botânico e naturalista franciscano Frei José Mariano Conceição Veloso (1742-1811), autor de Flora Fluminensis (que teve seu texto publicado em 1825 e os desenhos em 1827), e por fim, do médico e botânico Francisco Freire Alemão (1797-1874), que dirigiu o Museu Imperial, ao dizer:

É natural que não tenha escapado às pesquisas dos dois ilustres freires da flora brasileira, o Veloso e o Alemão; mas, como apesar de tanto dinheiro desperdiçado pelo Governo, as letras andam entre nós abandonadas à indiferença e ao 
charlatanismo, que são a medusa e o minotauro do talento, não me pude socorrer à ciência dos dois célebres botânicos..$^{20}$

Mas, se a passagem indica uma proximidade de preocupação da ciência e da arte em apreender a natureza, inventariá-la e descrevê-la, remetendo a questão do incentivo governamental a tais expedições contrapostas à da falta de apoio à publicação, às letras, momento seguinte, opôs os procedimentos do cientista aos do artista. Ricardo não só ignorava o teor do conhecimento produzido pelos cientistas, que elaboraram classificações, mas também distava de seus métodos e concepção daquilo que observava. "O modo por que ele admirava a pequena flor revelava o tato do artista ou do poeta. Seu exame nada absolutamente se parecia com a fria dissecação que o botanista opera nas diferentes partes de uma planta, para conhecer o seu gênero, classe e família". Como artista romântico, a via como ser vivo, semelhante aos animais e, após falar de sua forma e cor, acrescentava: "Falta-lhe o perfume, que é o coração da flor, a sua respiração". Com olhar e "enlevos de artista”, copiou "o arbusto em uma das páginas do álbum”, traçando "a lápis o esboço da planta”. A natureza permite ao viajante refugiar-se, o recolhimento em si mesmo e uma reflexão solitária. Ao examinar a flor, as “impressões poéticas” por ela despertadas "se enlearam com outras cimas", que absorveram o espírito do rapaz, as quais foram expressas num monólogo que tratou do ouro como "rei do mundo" e atrelou questões como sociedade, leis, homens, felicidade e ilusões, ao expressar suas "mágoas íntimas".

A Tijuca, com sua "formosa serraria”, era objeto de práticas culturais como a contemplação e era lugar de os ricos passarem o verão ou o fim de semana, não sendo considerada como espaço urbano, mas como campo, conforme o pensamento ocidental que estabeleceu a contraposição desses pólos. O campo, como espaço referente à natureza, era ocupado também por pequenos proprietários, que, com seu trabalho, sustentavam suas famílias. Abrigava pequenas propriedades e ainda pessoas pobres que se proviam com suas fruteiras, com os produtos de pequenas roças, da pescaria, da plantação de bananas, algumas linhas de cafeeiros e da criação de galinhas, que dava ovos e frangos, que podiam ser vendidos à cidade. D. Joaquina inseria-se nesse universo e morava numa pequena casa entre duas pontas da montanha, onde "um escasso ribeiro descia em cascata rumorejando por entre as pedras, e serpejava à sombra das bananeiras".22

A exploração econômica desse território, antes apontada em Diva, ${ }^{23}$ chegou a tornar tais montanhas a quase morros pelados, pela devastação no iní- 
cio do século para plantar café e pela extração de carvão e de madeiras para a construção civil e naval; portanto, não havia floresta por toda parte. Ricardo, certa feita, "lembrou-se de subir até a Floresta, um dos mais lindos sítios da Tijuca", e o narrador não deixou de fazer sua crítica à destruição da natureza ali ocorrida pela "cobiça do lucro", além de apontar a empresa de reflorestamento que Archer, engenheiro francês, realizava. Se, para reflorestar, o Barão de Bom Retiro e o Imperador designaram a desapropriação de fazendas, transformando-as em chácaras para os ricos e hotéis para os nem tanto, Archer, solitariamente, decidiu pela recomposição com espécies nativas.

O nome pomposo do lugar é por ora mais do que uma promessa; quando porém crescerem as mudas de árvores de lei, que a paciência e inteligente esforço do engenheiro Archer tem alinhado aos milhares pelas encostas, uma selva frondosa cobrirá o largo dorso da montanha, onde nascem os ricos mananciais. ${ }^{24}$

Para Alencar, esse trabalho representava uma "viva imagem da loucura humana", que devastava para depois "refazer à custa de anos, trabalho e dispêndio de grande cabedal, o que destruiu em alguns dias pela cobiça do lucro insignificante". Condenava a destruição da natureza pelo desejo do lucro, batia contra o homem civilizado e opunha os tempos do passado e o presente:

Aquelas encostas secas e nuas, que uma plantação laboriosa vai cobrindo de plantas emprestadas, se vestiam outrora de matas virgens, de árvores seculares, cujos esqueletos carcomidos às vezes se encontram ainda escondidos nalguma profunda grota. Veio o homem civilizado e abateu os troncos gigantes para fazer carvão; agora, que precisa da sombra para obter água, arroja-se a inventar uma selva, como se fosse um palácio. Ontem carvoeiro, hoje aguadeiro; mas sempre a mesma formiga, abandonando a casa velha para empregar sua atividade em construir a nova. ${ }^{25}$

As representações produzidas por Alencar, em diálogo com os relatos de viagem e com de participantes de expedições naturalistas, além da oposição natureza/civilização, registravam a dimensão pitoresca das paisagens, fundando-as e descrevendo-as de modo pictórico. Seu interesse era de estabelecer uma identidade nacional, ao ressaltar marcos e componentes naturais locais, como a vegetação, o relevo e os elementos hidrográficos, os quais ainda produziam transformações afetivas e psíquicas em quem entrava em contato com eles. Com a paisagem da Cascatinha, as preocupações de Ricardo "se desva- 
neceram completamente diante do quadro arrebatador que se oferecera a seus olhos". Numa perspectiva relacional, sua queda foi comparada ao manto de Agar, escrava de Sarah, esposa de Abrão, na Bíblia, além de contraposta a outras cascatas, ressaltando sua especificidade, reafirmando sua aproximação à figura de uma mulher e indicando-a como ponto de visitação de estrangeiros e da alta sociedade fluminense. ${ }^{26}$

Brancos lençóis de espuma se desdobravam pelas escarpas do rochedo, como as pregas de alvo manto flutuando sobre as espáduas de Agar, a africana. A vegetação se debruçando de um e outro lado, derrama sobre a cachoeira uma sombra doce, que torna mais negra a pedra e mais cândida a espuma ... Há cascatas muito mais ricas e abundantes do que essa, não só na grande massa das águas, como na vastidão e aspereza dos penhascos. Têm sem dúvida aspecto mais soberbo e majestoso; inspiram n'alma pensamentos mais graves e sublimes ... A Cascatinha da Tijuca, porém, prima pela graça; não é esplêndida, é mimosa; em vez da pompa selvagem respira uma certa gentileza de moça elegante; bem se vê que não é uma filha do deserto; está a duas horas da Corte, recebe freqüentemente diplomatas, estrangeiros ilustres e a melhor sociedade do Rio de Janeiro ... Assim não se despenha ela com a fúria de uma serpente ... Sua voz não é um trovão, mas um rumorejo que embala docemente o coração. Perto dela sente-se no ar o hálito fresco das águas que se esfrolam, e não a constante neblina produzida pelos borbotões que se desfazem em pó com a violência do choque. ${ }^{27}$

A visão da natureza permeada pela subjetividade romântica está expressa na busca de descrevê-la, de representá-la, expondo sentimentos e sensações experimentadas ao seu contato. Na procura de abarcar esse espetáculo, os oitocentistas lançavam mão não só da palavra falada e escrita para edificar imagens do cenário, como também do desenho e da pintura, que funcionavam como tentativas de garantir a memória, de expressar, guardar e transmitir as impressões vivenciadas na relação com a natureza. A queda d'água era objeto de contemplação e de produção artística, como "uma aquarela da formosa paisagem", que Ricardo "já possuía em seu álbum” e de "outra vista” que planejava tirar, pois "nunca a vira tão abundante de água, tão enfeitada e casquilha”. Desta forma, associando-a à imagem feminina, ele "teria a Cascatinha em traje de festa e em desalinho". A visão desta provocou a exclamação fervorosa da inglesa Mrs. Trowshy, mestra de Guida: “- Oh! beautiful! Very beautiful!” 28

A partir desse ponto, o conhecedor da cartografia do lugar podia tomar a direção da "Floresta, ou mais acima ao pico da montanha que tem a forma 
e o nome de Bico do Papagaio". Por outro lado, já "descendo o caminho da Cascatinha", era possível passear "na bela estrada" que ia ter ao Jardim Botânico. Embora a Tijuca não fosse considerada "muito extensa", ressaltava-se que, ainda assim, "oferecia vários passeios", o que possibilitava estabelecer um programa habitual de excursões como à Vista Chinesa, à Vista do Mar, à Mesa, à Cascata Grande, à Barra, à Boa Vista, à Restinga, à Pedra Bonita, ao Canto da Saudade e ao Bico do Papagaio. Por estradas e trilhos, que compunham uma rede de caminhos, os quais o romance mapeava, encontravam-se comitivas de "diversas pessoas, senhoras e homens, que iam de passeio, rindo e conversando", e até mesmo a imaginar aventuras e fortes emoções, como fazia Mrs. Trowshy, que indicava a presença ali de escravos fugidos do cativeiro que edificavam na região quilombos na busca da liberdade, ao temer ataques dos "salteadores da Tijuca, chamados quilombolas", que "furtavam bananas, galinhas e outras cousas leves...." 29

A paisagem da Tijuca oferecia a um artista, como um pintor, ou quem, nas horas de lazer, gostava de desenhar, rica matéria para sua produção. Guida, que não conhecia Ricardo, chegou a supor que talvez fosse ele "algum pintor que percorria os sítios da Tijuca para copiar perspectivas, que mais tarde lhe servissem de assunto a algum quadro a óleo", pois trazia sempre nos passeios a pé o álbum de desenho. Além disso, a serra não possuía apenas uma face e aspecto, apresentava dois lados distintos da natureza fluminense, constituindo-se em fecunda fonte para a produção de imagens. Com essa descrição pictórica, em interlocução com outras produções discursivas e imagéticas, Alencar tomava posição na polêmica que afirmava que a natureza do Novo Mundo era inferior à do Velho, por ser ainda adolescente, ao concebê-la como traço "da primeira carcaça do globo". ${ }^{30}$

DO LADO que olha para o mar, a serra da Tijuca apresenta um aspecto muito diferente. As encostas que descem para o Andaraí, como os vales e eminências que se encontram pelo dorso da montanha, têm a fisionomia risonha e pitoresca: são ondulações amenas ou recortes caprichosos, que deleitam a vista.

$\mathrm{Na}$ outra face, a natureza é agreste; dir-se-ia uma terra convulsa. O fogo subterrâneo ferveu nas entranhas da terra, e rasgando-lhe os flancos, arremessou aqui e ali pelas encostas aqueles enormes calhaus ou maciços de rocha, fragmentos da primeira carcaça do globo.

A superfície da terra conserva ainda um aspecto combusto e árido; vê-se que por aí passou a lava em tempos remotos. De espaço a espaço o trabalho do ho- 
mem cobriu a encosta da montanha de plantações; mas entre esses pontos cultivados destaca-se ainda mais a bronca aspereza dos sítios agrestes. ${ }^{31}$

Na elaboração do mapa do lugar, indo para a banda onde a "natureza é agreste", Ricardo, o viajante que descreve a paisagem, fez, algumas vezes, "excursão até a Cascata Grande, um dos pontos mais freqüentados pelas pessoas que passam o verão na Tijuca”. Porém foi ainda mais longe, ao passar pela Barra e chegar à Restinga. Outras vezes, voltando-se para o lado do mar, foi à Pedra Bonita, que "é uma rocha que se levanta sobre um cabeço de montanha como um gorro de granito". Conforme o narrador, "Daí, dessa atalaia das nuvens, goza-se uma vista soberba sobre o mar, e vê-se de perto o enorme cesto da Gávea, habitualmente cingido de vapores”. Entre os visitantes do lugar, os de nacionalidade inglesa possuíam primazia. "Como todos os belos sítios da Tijuca, a Pedra Bonita é muito freqüentada pelos filhos da loura Albion, incansáveis exploradores desse belo arrabalde do Rio de Janeiro". Sobre a presença dos ingleses aí, tinha lá o imaginário social seus registros marcados pela peripécia, pela aventura no contato com esse ambiente e sua grandiosidade: "Contam que um inglês aí se perdera, ficando sobre o gigantesco pedestal de rocha, elevado à condição de estátua, durante três dias, sem comer nem beber", pois foi o penedo "mais fácil de subir que de descer". Essa representação das figuras humanas minúsculas diante da grandiosidade da natureza foi recorrente nas artes oitocentistas, inclusive em Fenimore Cooper, de quem Alencar foi leitor assíduo, o que aponta ainda a circularidade e intertextualidade das práticas culturais. ${ }^{32}$

Num procedimento relacional, experimentava-se a ambigüidade de recorrer aos padrões culturais europeus, diante dos quais se curvava, mas, ao mesmo tempo, buscava-se na natureza local a base para a construção da identidade e afirmação nacional. Ao referir-se à marcante presença inglesa no "belo arrabalde", Alencar dizia que os imigrantes "ingleses herdaram dos jesuítas" o "sentido da higiene" e, como "a poderosa Companhia", que "foi deixando conventos nas situações melhores, tanto de salubridade como pela formosura”, possuíam o "mesmo faro do belo e do saudável”. Com visão estética e preocupações sanitárias e funcionais, essa gente, "chegando ao Rio de Janeiro, volve os olhos para a cinta de montanhas que cerca a cidade, e considera isso um sobrado natural que a Providência construiu por cima do escritório para alcova de dormir". Portanto, o narrador observava que, embora pesasse "ao nosso amor-próprio nacional, eles naturalizaram inglesa, a nossa Tijuca; fizeram daquela serra onde campearam os Tamoios, uma Escócia brasileira".33 
Enfatizando, ainda, a presença dos imigrantes ingleses que, com suas idéias e costumes, transformava a realidade cultural nativa e local, contrapôs o momento presente aos tempos de outrora, ao indicar aspectos da cultura inglesa que substituíram os costumes dos habitantes primitivos, os indígenas: "O grito dos highlanders percorre as formosas encostas. Pelas grotas onde reboava primitivamente o brado selvagem da pocema, ouve-se agora repetido de vale em vale pela voz suave das amazonas o gracioso la-la-hi-ti”. Diante das muitas transformações culturais marcadas pela influência estrangeira, a recorrência nativista encontrava na cultura dos índios os sinais do próprio e original. Alencar avançou na idéia da presença marcante dos ingleses no conhecimento e exploração das belezas do espaço, ponderando:

Se quereis ver o que há de mais belo e encantador naquele arrabalde, procurai o conhecimento de algum filho da Grã-Bretanha. Ele conhece a Tijuca de uma à outra extremidade, desde a gruta mais funda até o pico mais alto. Sabe não só dos vários passeios, como do dia e da hora em que se deve apreciar cada um deles. Afinal, quando tiverdes visto toda a Tijuca já descoberta e explorada, o inglês inventará uma pedra ainda não conhecida e uma excursão como a de subir à Gávea por um caminho de lagarto. ${ }^{34}$

Mas Alencar não só ocupou-se das descobertas e explorações dos ingleses na natureza da Tijuca. Num âmbito mais geral, apontou a prática dos cientistas ingleses de explorar as riquezas botânicas brasileiras e nomear seus elementos naturais com nomes estranhos ao meio e cultura de origem, como forma de homenagear seus governantes. $\mathrm{Da}$ "flor gigante" dizia:

a grande ninféia escarlate, a rainha dos lagos, que os ingleses chamaram "vitória”, em honra de sua soberana, mas eu chamarei "imperatriz", em razão de ser uma majestade brasileira. Dir-me-ão que não sou botânico, e portanto não tenho autoridade para crismar essa espécie de loto, que os indígenas chamavam "milho-d'água". Não é decerto minha intenção invadir os domínios da ciência. Podem os botânicos inventar quanto nome grego e latino lhes aprouver para apelidarem as plantas; podem fazer a autópsia das inocentes criaturas para reduzi-las a sistema; mas as flores, como mimos da natureza, pertencem à literatura; são do domínio da poesia. ${ }^{35}$

A Tijuca tinha também marcas da circularidade cultural deixada pela presença de imigrantes de outras nacionalidades, como indicava a denomi- 
nação Vista Chinesa, para o "magnífico cenário” no qual foi construída "a palhoça onde pousavam os colonos" chineses, "que abriram o caminho do Jardim e deram nome ao sítio”. O lugar, associado à imigração implementada vinda do oriente, a princípio ficou conhecido "pela simples indicação de Rancho dos Chins", mas "a imaginação popular enlevada pela brilhante perspectiva, de lembrança fantasiava alguma das pinturas diáfanas e aveludadas que vira debuxadas em papel de arroz: e daí o nome de Vista Chinesa”. Aí ocorriam piqueniques debaixo do "nemoroso bosque dos bambus" com "banquetes dados sobre ... rude estiva de varas, sem toalha nem serviços de prata, mas tão opíparos de contentamento e prazer". Bambus que "guardam em hieróglifos e datas" segredos gravados nos "verdes troncos das taquaras", com garfos e canivetes, por aqueles que ali iam e deixavam como "lembrança do passeio" uma escritura; "uns o nome e data; outros a simples inicial". As cenas de pessoas contemplando a paisagem magnífica sobre um relevo saliente e o expediente de gravar seus nomes no arvoredo indicam práticas culturais que circulam em várias sociedades e um diálogo rico estabelecido por escritores de nacionalidades variadas assim como com pintores nesse período. ${ }^{36}$

O olhar alencariano, ao procurar definir uma identidade e um lugar, tanto para a cidade quanto para o Brasil, contrastou, equiparou e elevou a paisagem da Tijuca ao mesmo patamar daquelas de países europeus, bem como as ações de seu povo, como sujeitos, na construção de símbolos culturais que marcassem o imaginário nacional. Nesse sentido, a princípio, ele inseriu essa paisagem num álbum folheado numa sala, no qual apareciam "lindas vistas da Suíça, da Escócia, de Sintra e da Tijuca”. Posteriormente, o Dr. Nogueira, ao ver as paisagens suíças chamou a atenção para o aspecto da construção da figura dos heróis nacionais, falando de Guilherme Tell, o libertador, que teve sua história transformada em ópera por Rossini. Esse personagem confrontou a habilidade do europeu à dos nativos brasileiros e enalteceu os últimos. Como a ópera tratava da fama de Tell como arqueiro destro, que foi obrigado por Gessler, governador tirano e cruel, a atirar uma flecha numa maçã sobre a cabeça do próprio filho e o deixou incólume, Nogueira, em contraposição, tratou da destreza dos índios. Disse que "a perícia do alemão nada é à vista da destreza dos selvagens do Brasil", que "faziam cousas incríveis", como furar "os olhos de um pássaro a voar" e flechar "o peixe dentro da água”. Mas, além de equiparar o feito do herói camponês com as práticas dos selvagens brasileiros, bateu contra a comemoração do dia 7 de setembro, considerando que nesta "bajulam-se os reis e os grandes; mas não se honra a nação", o que afetava os "brios nacionais". Ainda para enaltecer os feitos e figuras nacionais em 
oposição àqueles da história da Suíça, remeteu a Friburgo como cidade "célebre por sua ermida, que um homem só cavou na rocha viva trabalhando vinte e cinco anos", para, em seguida, enfatizar que ouvira "contar um fato análogo, sucedido em Minas", que, se verdadeiro, “é mais para admirar porque foi um aleijado dos braços que trabalhava com os pés, e assim construiu uma capela". ${ }^{37}$

No entanto, o ápice de tal processo de comparação, que punha em contraste aspectos variados e em destaque os selvagens brasileiros e a figura de Aleijadinho como um símbolo da cultura nacional, realizou-se ao explanar sobre "Genebra e o seu belo lago", "pátria de Rousseau, de Calvino, de Staël e outros personagens ilustres". Nogueira, ao fazer uma "viagem a vôo de pensamento pelas montanhas da pitoresca Helvécia”, descreveu "o aspecto dos campos e bosques durante o inverno, e aquela natureza áspera e desabrida", ao passo que lançava a base do confronto em torno da natureza tropical, que fora apenas indicada na passagem do álbum que continha paisagens da Tijuca a par das européias. Nesse ponto, Alencar não traçou explícita e imediatamente o paralelo das montanhas suíças com aquela da ensolarada Tijuca no verão, deixando tal exercício para o leitor, que, já imerso no território e ambiente, por aquilo já mostrado, recebia nova bateria de imagens desse sítio, permeadas de crescente ufanismo. ${ }^{38}$

Para mostrar a monumentalidade, as maravilhas e a originalidade dessa natureza tropical, Alencar pôs seus personagens em comitiva rumo à Vista Chinesa, avançando em sua descrição da paisagem e do mapeamento do território. Alguns apareceram de madrugada, como um grupo de senhoras que voltava do banho de mar vindo dos lados da Boa Vista, para compor a "luzida companhia”. Elas, pelo horário, estavam em conformidade com as prescrições da medicina, que, na busca de regulamentar a vilegiatura, como a marítima, que de terapia tornava-se moda, como na Europa, estipularam horários e trajes para as práticas. Depois, foram vistos na estrada do Jardim, como era "conhecido o caminho que serpejava pelas encostas da serra da Tijuca, e contornando a base da montanha desde a Cruz, no Alto da Boa Vista, ia morrer nas praias de Copacabana”. No percurso, a contemplação da paisagem era habitual e "em uma aberta do mato que borda o caminho, avistaram os passeantes ao longe a barra da Tijuca, ao longo da qual estendia-se o cordão de espuma das vagas, como uma franja de armarinho, guarnecendo o manto de cetim do oceano, a embeber o azul do céu". Olhando a tal vista, descrita de modo plástico, "saudaram com uma exclamação de prazer o quadro encantador daquela marinha, tocada pelos raios do sol nascente, que aveludava as cores mi- 
mosas da palheta americana”. Já avistando o Canto da Saudade, “os olhos desafogados do arvoredo que vestia a orla do caminho, se desdobraram ávidos pelos horizontes abertos, recreando-se com a paisagem de várias chácaras, derramadas no vale, ou alteadas pelas assomadas das fronteiras colinas". Entre tais casas de campo, estavam "a do Moke" que, "por ser das residências mais antigas que se estabeleceram nesse aprazível sítio; e do Dr. Cócrane [sic], arranjada à feição de um modesto parque inglês", atraíam grande número de visitantes. ${ }^{39}$

Esse "aprazível sítio" da Tijuca e a residência de Cochrane tiveram para Alencar significado especial. Nas suas passagens por ali, conheceu o afamado médico, vindo a casar-se com uma de suas filhas, Georgiana Augusta Cochrane. Por ser a Tijuca espaço de uma estação de veraneio na montanha, que, como na Europa, entrou em moda, lugar silencioso e tranqüilo, onde se podia isolar e pensar, refazer as experiências, restabelecer a saúde e sensibilidade, Alencar, em 1864, esgotado e doente, retirou-se da Corte, por recomendação médica, na busca de melhores ares, hospedando-se no Hotel Bennet. Dessa circunstância, conheceu o médico ao sair para passeios pelos arredores, como indo à Cascatinha e a cavalo até a Vista Chinesa, passando a freqüentar o sítio Castelo e a namorar Georgiana, casando-se no mesmo ano. Não hesitam os biógrafos em enfatizar que Sonhos d'ouro é uma transposição de sua história para o romance e que "fora de dúvida", no livro, o "romancista fizera um auto-retrato", havendo "uma infinidade de traços correspondentes", sendo Georgiana e Alencar retratados em Guida e Ricardo. Referindo-se a sua presença na residência, o narrador disse: "Talvez nessa ocasião percorria o escritor destas páginas as bordas do lago sereno, em seu passeio matinal, bem longe de imaginar que teria de referir a comédia, cujas figuras principais passavam ao longe, sem que ele as percebesse". 40

Seguindo a comitiva expedicionária, que ia observando e adjetivando as imagens da natureza fluminense, esboçadas de forma plástica, ao chegar à Vista Chinesa podia-se "contemplar o esplêndido cenário que se desdobrava em face" dos visitantes. Avistava-se, "Além, na extrema, campindo os horizontes do soberbo painel, o oceano calmo e sereno que se vinha desdobrar até babujar com branca orla de espuma as praias de Copacabana e de Marambaia". Era essa "a tela onde se estampava com vivo colorido, sobre o campo azul, a magnífica paisagem”, que levou Alencar a opor tais belezas a outras criadas pelo imaginário da literatura universal e que davam identidade ao oriente, dizendo: "Um jardim encantado, como se desenha à imaginação, quando lemos aos vinte anos os contos das Mil e uma noites; um sonho oriental debu- 
xado em porcelana ou madrepérola; tal era o quadro deslumbrante que debuxavam aquelas encostas". Continuando a expor seu olhar, que apreendia a natureza nessa incursão, a nomeava e a inventava como monumento da cidade e nação, mesclada com o jardim artificial, que assume ar de natural, descrevia:

Lá, no mar, as ilhas que fingem ninhos de gaivotas, a se balouçarem ao reflexo das ondas. Na praia junto à Lagoa, as alamedas do Jardim Botânico, recortando em losangos os maciços da folhagem; e as palmeiras imperiais meneando às brisas da manhã os seus verdes cocares ... Não vês junto ao sítio aprazível um enorme caramelo, servido sobre uma taça da mais pura safira, como a promessa dos regalos que a natureza americana oferece aos que visitam suas plagas? ... É o Pão de Açúcar, no esforço a que o reduzem a distância e a eminência, donde o avistamos ... A nossos pés, o gigante de pedra, o prócero Corcovado, que o nauta demanda da barra antolha-se como o guarda desse jardim das Hespérides e daqui parece agachado, como um anão, à base da grande montanha que nos serve de pedestal. ${ }^{41}$

Para Alencar, a beleza e os elementos que compunham o relevo carioca não eram tudo, atribuía destaque à sua luminosidade; o que "dava a essa perspectiva um aspecto fascinador, era sobretudo a diáfana limpidez do ar, e uma plenitude da luz que estofava os objetos, cobrindo-os com uma espécie de áurea expansão". Avaliava que "Não se podia chamar resplendor, porque não reverberava nem deslumbrava os olhos; era antes uma pubescência, doce e aveludada, onde se engolfavam os olhos com delícia”. Diante da paisagem iluminada, "derramaram-se os passeantes pela borda da esplanada para melhor apreciar os vários pontos da perspectiva, e cruzaram-se as observações de toda a casta, e as réplicas ou risos que elas provocavam”. Fábio mostrava "o admirável panorama” e dizia que a imagem era "o reino das fadas"; Mrs. Trowshy, "estatelada diante daquela magnificência", exclamava: “- Fairy!... Fairy!" até que, "no seu entusiasmo”, falou: “-Look, Sir, how beautiful!”. Já o visconde, à parte, "parecia enlevado ante a cena maravilhosa; tal concentração de espírito mostrava sua atitude contemplativa”. Portanto, diante do espetáculo oferecido pela paisagem natural, "cada um quis deixar nos bambus uma lembrança do passeio" encantador, imprimindo uma marca de sua presença no belo lugar. ${ }^{42}$

Alencar finalizou a apresentação de seus esboços pictóricos dos elementos naturais que constituíam a paisagem ao redor da baía, numa conversa so- 
bre o passeio à Vista Chinesa, considerado "magnífico” por Ricardo. Nosso viajante provinciano, que descobria o lugar e suas belezas, assim os avaliou: “-É um panorama admirável; não creio que haja no mundo uma tela igual...”. Em seguida, o rapaz fez a seu "companheiro a descrição pitoresca da Tijuca", dizendo: “- Mais bonito do que a Vista Chinesa, é o Bico do Papagaio", onde se podia "comparar os dois picos" e considerar que "No de lá há justamente por cima do nariz da pedra uma árvore que finge bem um chapéu de sol!”."3

Desta forma, Alencar elegia alguns aspectos físicos da natureza fluminense como o mar, praias, floresta, montanhas, rochas, ilhas e sol como símbolos da cidade, que davam a ela individualidade, assim como à nação que tinha a Corte como sua representação e emblema. Ao fazê-lo, inseriu-se no processo de invenção de uma tradição do Rio de Janeiro como cidade maravilhosa, coração do Brasil, cheia de recantos e encantos mil como Copacabana, Tijuca, Lagoa, Corcovado, Pão de Açúcar... espaços vazados pelo sol do verão e cenário de namoros e amores. A natureza, o relevo do lugar, as rochas e pedras foram descritos de modo a ressaltar a originalidade do local e elevados à condição de monumentos da cidade e do país. Sobre ela, elaborou representações plástico-literárias, fundantes da cidade e de um Brasil a partir da paisagem natural, que expressavam formas de ver mundo e que contribuíram, com a criação de imagens, para edificar a identidade do lugar e da nação. Os elementos apresentados pelo romancista instituíram um repertório no modo de ver a cidade, que permeiam até hoje nossa memória coletiva, os quais foram, na década de 1930, sintetizados simbolicamente, por André Filho, no coro e na última estrofe da marcha "Cidade Maravilhosa", que se tornou hino do Rio de Janeiro. ${ }^{44}$

No século XIX, muitos olhares voltaram-se para a natureza brasileira, produzindo representações e um imaginário sobre esta. Imagens escritas e iconográficas, fruto do cientificismo e da sensibilidade artística romântica, que perpassaram pelo conhecimento do país. Olhares sobre a natureza grandiosa, nos quais se interpenetravam sensibilidades, juntavam-se elementos que adquiriam forma, que, no conjunto, constituíram base e material para as primeiras construções elaboradas a respeito da nação brasileira e de sua identidade. A sensibilidade romântica realizou a aproximação entre ciência e estética ao apreender e representar a natureza, numa visão totalizante e orgânica, na procura de obter o conjunto, inaugurando uma nova concepção de paisagem e a tentativa de inventar e visualizar a nação. Procurando afirmar a individualidade da natureza local e brasileira e contestar as afirmações de sua inferioridade, até mesmo os animais entraram na disputa marcada pelo 
estabelecimento de contrastes. Se os viajantes europeus, desde o século XVIII, deslocaram-se pelo mundo na busca de regiões tidas como exóticas para observar, medir e classificar a flora, a fauna, as rochas, as montanhas e os rios, o que conferia certa identidade ao país ou região, sinalando singularidades, identificando distinções e o original, Alencar fez-se presente nessa arena ao traçar representações que contrapunham ainda alguns animais eqüinos. ${ }^{45}$

Cavalos de diferentes raças, um racé, da milionária fluminense Guida, um crioulo dos campos de Curitiba, do jovem e pobre advogado paulista Ricardo, e as mulas paulistas de um tropeiro, que, enriquecido, se tornou barão, foram comparados entre si. Edgard, o racé, foi descrito como possuindo porte "alto, airoso, de uma estampa soberba, respirava a elegância altiva e serena, que lhe imprimira a educação britânica". Como "cavalo do cabo, de boa raça, tem alguma cousa do lord: a mesma fleuma aristocrática, o mesmo garbo frio e impassível, a mesma sobriedade do gesto". Era "o cavalo por excelência, o fidalgo de raça, o gentleman da estrebaria". Na sua atitude, "não se via a impaciência fogosa, a vivacidade sôfrega, que sem dúvida ressumbraria no filho da raça brasileira, apesar de muito afastado de sua primitiva estirpe árabe”. O "lindo isabel" estacava "imóvel, com a firmeza correta de uma posição acadêmica", pisava com "rígida elegância”, erguia a cabeça "com arrogância” e "olhar oblíquo do orgulho desdenhoso". Já Galgo, "o cavalo brasileiro", "curitibano", era de "briosa independência", "vivo, ardente e prazenteiro", "fogoso", "um animal arisco", "um caipira". No confronto, a representante da cultura estrangeira, a inglesa Mrs. Trowshy, considerava Galgo um "monstro", "fogoso", não havendo parâmetro de comparação. Já Guida o achava "muito bonito"; observava que Edgard era "um cavalo de preço, um cavalo de raça”, tinha "estampa mais vistosa e elegante", mas era frio, "não sabia brincar". Logo, julgava "o outro mais bonito", via nele elementos como a "graça dos movimentos", destacava que era "vivo e faceiro", brincava, possuía "alegria" nos olhos e "garbo" ao mover o pescoço. ${ }^{46}$

No desfecho da disputa, procurou-se provar que Galgo era o animal adequado ao meio natural brasileiro, demonstrando ser "acostumado aos morros", caminhos "bastante íngremes", "encostas rudes, cortadas em rápido talude e profundamente sarjadas pelos sulcos das torrentes que descem do cimo da serra quando chove", sendo ágil, firme, forte e possuidor de elasticidade. Se, num passeio pela Tijuca, Guida impeliu Edgard contra o despenhadeiro para apanhar a flor dourada a duas braças ladeira abaixo, e ele, fustigado, refugava irritado, caminhando para precipitar-se, Ricardo, depois de impedi-lo e de ouvir alguém pronunciar que "não há cavalo capaz de fazer isto", quis 
mostrar o contrário. O moço "sentiu despertar-se-lhe o zelo pelos brios do Galgo". Assim, em seguida, "descia com admirável agilidade e firmeza o sinuoso barranco", apoiando o casco na estreita borda do sulco; "desceu e subiu sem vacilar um passo, com plena confiança na força e elasticidade de seus músculos". O "cavalo, correspondendo dignamente ao nome galgou com ligeireza o caminho". 47

Portanto, Guida passou a achar seu isabel "um poltrão", que "teve medo de descer" uma ladeira, embora escarpada, mostrando-se resolvida a vender Edgard. Ofereceu-o ao barão, seu pai, velho tropeiro e conhecedor de animais, e esse lhe disse: “- Não; eu cá, não deixo a minha mula paulista. Esses cavalos da moda, que vocês apreciam por serem muito grandes e muito caros, não me servem ... não quero negócio ... não me logres”. Além de contrapor o cavalo curitibano ao estrangeiro, destacou o valor dos muares paulistas como animais de tropa e transporte de passageiros, sobre os quais se ergueram e circularam muitas riquezas e fortunas, como aquelas de vários dos comensais da casa da moça. Assim, também, buscou-se afastar a idéia de que a natureza americana era inferior à do Velho Mundo, pois os animais eram de porte menor, e aqueles que vinham da Europa aqui não se adaptavam, diminuíam de tamanho e deterioravam. ${ }^{48}$

Fechando esse problema sobre a construção do imaginário nacional por meio da natureza, cabe ainda mencionar que, tal como em outros escritores americanos, aqui também se remeteu à visão médica de sua força regeneradora da saúde debilitada e da benéfica comunhão dos indivíduos com esta. Como, após o afastamento de Guida e Ricardo, a saúde dela se alterara, perdendo a "vivacidade", parecendo "que estava desmaiada", até chegar ao "desfalecimento" e inquietar a família, "os médicos receitaram as duas panacéias do costume, 'o casamento' e 'o campo'”. Ao escolher o arrabalde para onde ir, indicado como terapia, Guida pediu a Tijuca. Não que ela esperasse tirar proveito para a saúde, mas "era um desejo recôndito de rever aqueles sítios, e saciar-se das reminiscências que eles guardavam", por mais que "matassem" as árvores, "como a mancenilha; queria embriagar-se de seus perfumes". Nesse lugar de suas memórias, a moça, que já desejava a morte, num de seus passeios reencontrou Ricardo e reconquistou a vontade de viver, fechando o círculo que unia natureza, saúde, amor e casamento. ${ }^{49}$

Desta forma, Alencar forjava em sua escritura imagens instituintes não só da cidade do Rio de Janeiro mas da própria nação brasileira, pondo em relevo aspectos que lhes davam singularidade e estipulavam alguns traços identitários. Imagens nas quais natureza e cultura, história e sociedade, são ele- 
mentos inerentes e imbricados, constituintes de sua narrativa literária, pelos quais estabelece marcos e monumentos fundantes de uma identidade nacional e da cidade. Suas representações, nesse romance, assentam os alicerces de um repertório básico recorrente na construção do imaginário do Rio de Janeiro identificado como cidade maravilhosa, onde o viajante desfruta de belas paisagens naturais que influem, inclusive, nas suas manifestações afetivas e psíquicas. O romance em si, com suas descrições do espaço e do ambiente natural em intercâmbio com o campo da cultura e da história, é uma realização da fórmula que tanto buscou erigir para formatar uma literatura brasileira e representar a nação.

\section{NOTAS}

${ }^{1}$ ALENCAR, J. O nosso cancioneiro. In: Obra completa. Rio de Janeiro: José Aguilar, 1960. v.4, p.961, 972, 982-3; Bênção paterna (Prefácio de Sonhos d'ouro). In: Ficção completa e outros escritos. Rio de Janeiro: Aguilar, 1965. v.1.

${ }^{2}$ BOECHAT, Maria Cecília B. Paraísos artificiais: o romantismo de José de Alencar e sua recepção crítica. Belo Horizonte, 1997. 169p. Tese (Doutorado em Letras) — Faculdade de Letras, Universidade Federal de Minas Gerais. p.118-9; PROENÇA, M. C. Alencar na literatura brasileira. In: ALENCAR, 1965, v.1, p.34.

${ }^{3}$ ALENCAR, 1965, v.1, p.491; FERREIRA, T. M. da Cruz. Palácios de destinos cruzados: bibliotecas, homens e livros no Rio de Janeiro, 1870-1920. Rio de Janeiro: Arquivo Nacional, 1999, p.78.

${ }^{4}$ ALENCAR, 1965, v.1, p.493; DE MARCO, Valéria. O império da cortesã: Lucíola, um perfil de Alencar. São Paulo: Martins Fontes, 1986. p.49.

${ }^{5}$ ALENCAR, 1965, v.1, p.494-5.

${ }^{6}$ Ibidem, p.495; SCHAPOCHNIK, N. Letras de fundação: Varnhagen e Alencar — projetos de narrativa instituinte. São Paulo, 1992. 245p. Dissertação (Mestrado em História) — Faculdade de Filosofia, Letras e Ciências Humanas, Universidade de São Paulo. p.43, 53-4.

${ }^{7}$ ALENCAR, 1965, v.1, p.495-6.

${ }^{8}$ Ibidem, p.496.

${ }^{9}$ Ibidem, p.497.

${ }^{10}$ Ibidem, p.498.

${ }^{11}$ FIORIN, José Luiz. O descobrimento da língua brasileira. In: BRAIT, Beth; BASTOS, N. (Org.) Imagens do Brasil: 500 anos. São Paulo: Educ, 2000. p.155, 157; SCHAPOCHNIK, 1992, p.63-4. 
${ }^{12}$ ALENCAR, J. de. Os sonhos d'ouro. In: Obra completa. Rio de Janeiro: José Aguilar, 1960. v.4, p.935-6.

${ }^{13}$ Ibidem, p.936-9.

${ }^{14}$ ALENCAR, J. de. Cinco minutos. In: Ficção completa e outros escritos. Rio de Janeiro: Aguilar, 1965. v.1, p.160-2, 166, 173-9, 182-3.

${ }^{15}$ DE MARCO, Valéria. Uma história de sonhos, uma história de ouro. In: ALENCAR, J. de. Sonhos d'ouro. São Paulo: Ática, 1981. p.6; PRADO, Maria Ligia Coelho. América Latina no século XIX: tramas, telas e textos. São Paulo: Edusp; Bauru (SP): Edusc, 1999. p.180, $184,187$.

${ }^{16}$ MACFARLANE, Alan. A cultura do capitalismo. Rio de Janeiro: Zahar, 1989. p.177.

${ }^{17}$ ALENCAR, Bênção paterna, p.493; Sonhos d'ouro, 1965, v.1, p.500-1.

${ }^{18}$ ALENCAR, Bênção Paterna, p.493-4, 498; Sonhos d'ouro, v.1, p.513.

${ }^{19}$ Ibidem, p.499, 536; SÜSSEKIND, Flora. O Brasil não é longe daqui: o narrador; a viagem. São Paulo: Companhia das Letras, 1990. p.211 passim.

${ }^{20}$ ALENCAR, Sonhos d'ouro, p.500.

${ }^{21}$ Ibidem, p.500-1.

${ }^{22}$ Ibidem, p.512, 513, 516, 525; NAXARA, Márcia Regina Capelari. Natureza e identidade: três narrativas e a natureza Brasílica. In: SEIXAS, J. A.; BRESCIANI, M. S.; BREPOHL, M. (Org.) Razão e paixão na política. Brasília: Ed. UnB, 2002. p.136.

${ }^{23}$ ALENCAR, J. Diva. In: Ficção completa e outros escritos, v.1, p.355. O narrador indica a ação destruidora que envolvia o crescimento da cidade dizendo: "O arrabalde era naquele tempo mais campo do que é hoje. Ainda a fouce exterminadora da civilização não esmoutara os bosques que revestiam os flancos da montanha. A rua, esse braço mil do centauro cidade, só anos depois espreguiçando pelas encostas, fisgou as garras nos cimos frondosos das colinas. Elas foram outrora, essas lindas colinas, a verde coroa da jovem Guanabara, hoje veja regateira, calva de suas matas, nua de seus prados". Continuando sua queixa diante de tais mudanças, observa que: "Caminhos íngremes e sinuosas veredas serpejavam então pelas faldas sombrias da montanha, e prendiam como um braço as raras habitações que alvejavam de longe em longe entre o arvoredo. Límpidas correntes, que a sede febril do gigante urbano ainda não estancara, rolavam trépidas pela escarpa, saltavam de cascata em cascata, e iam fugindo e gargalhando aconchegar-se nas alvas bacias debruadas de relva".

${ }^{24}$ ALENCAR, Sonhos d'ouro, p.517; Diva, p.355; PÁDUA, José Augusto. Um sopro de destruição: pensamento político e crítica ambiental no Brasil escravista (1786-1888). Rio de Janeiro: Jorge Zahar, 2002, p.224-5; DRUMMOND, José Augusto. O jardim dentro da máquina: breve história ambiental da Floresta da Tijuca. Estudos históricos, Rio de Janeiro, v.1, n.2, p.276-98, 1988. p.294.

${ }^{25}$ ALENCAR, Sonhos d'ouro, p.518.; DE MARCO, p.6. 
${ }^{26}$ ALENCAR, Sonhos d'ouro, p.518; NAXARA, 2002, p.137; SÜSSEKIND, 1990, p.38, 40, 46.

${ }^{27}$ ALENCAR, Sonhos d'ouro, p.518.

${ }^{28}$ NAXARA, 2002, p.140; ALENCAR, Sonhos d'ouro, p.518.

${ }^{29}$ Ibidem, p.520, 524-5; SÜSSEKIND, 1990, p.35.

${ }^{30}$ ALENCAR, Sonhos d'ouro, p.533, 524-5; PRADO, 1999, p.183.

${ }^{31}$ ALENCAR, Sonhos d'ouro, p.533, 524-5; PRADO, 1999, p.183.

${ }^{32}$ ALENCAR, Sonhos d'ouro, p.525, 530; PRADO, 1999, p.192.

${ }^{33}$ Ibidem, p.190; ALENCAR, Sonhos d'ouro, p.530.

${ }^{34}$ Ibidem, p.530- 1 .

${ }^{35}$ Ibidem, p.539-40.

${ }^{36}$ Ibidem, p.577, 581; PRADO, 1999, p.192-3.

${ }^{37}$ ALENCAR, Sonhos d'ouro, p.542, 550-2.

${ }^{38}$ Ibidem, p.552.

${ }^{39}$ Ibidem, p.566, 569-71; CORBIN, Alain. O território do vazio: a praia e o imaginário ocidental. São Paulo: Companhia das Letras, 1989. p.69-108. Especificamente sobre a prescrição do horário, ver p.80.

${ }^{40}$ ALENCAR, Sonhos d'ouro, p.571; MAGALHÃES JR, R. José de Alencar e sua época. Rio de Janeiro: Civilização Brasileira; Brasília: INL, 1977. p.166-71; RODRIGUES, Antonio E. M. José de Alencar: o poeta armado do século XIX. Rio de Janeiro: Ed. FGV, 2001. p.101-2; MENEZES, Raimundo de. José de Alencar: literato e político. Rio de Janeiro: Livros Técnicos e Científicos, 1977. p.183-99; AMORIM, J. Edilson de. A ficção da corte (Romance e representação social em J. Manuel de Macedo, M. Antônio de Almeida e J. de Alencar). 232p. João Pessoa, 1989. Dissertação (Mestrado em Letras) - Curso de Pós-graduação em Letras, Universidade Federal da Paraíba. p.160; MARTIN-FUGIER, Anne. Os ritos da vida privada burguesa. In: PERROT, M. et al. História da vida privada. 4: da Revolução Francesa à Primeira Guerra. São Paulo: Companhia das Letras, 1991. p.231-2.

${ }^{41}$ ALENCAR, Sonhos d'ouro, p.579-80; SÜSSEKIND, 1990, p.24-6.

${ }^{42}$ ALENCAR, Sonhos d'ouro, p.580-1.

${ }^{43}$ Ibidem, p.588; SÜSSEKIND, 1990, p.28-9.

${ }^{44}$ A marcha "Cidade Maravilhosa”, com letra e música de André Filho, foi lançada em outubro de 1934, cantada por Aurora Miranda e por seu próprio autor. Seu coro (Cidade maravilhosa,/ Cheia de encantos mil...) emprega as mesmas adjetivações e associações realizadas por Alencar, de modo consecutivo e bem próximas (todas entre as páginas 579 e 581), como o adjetivo maravilhosa, a idéia de magia, encanto, de reino de fadas e o quantitativo mil, que ele associou à tradição do sonho oriental das histórias contadas ao sultão. 
Mesmo na última estrofe da letra o imaginário tecido é o mesmo, envolvendo elementos como jardim florido, amor, saudade, terra que seduz, sonho e luz.

${ }^{45}$ NAXARA, 2002, p.157; NAXARA, Márcia. Natureza e civilização: sensibilidades românticas em representações do Brasil no século XIX. In: BRESCIANI, Stella; NAXARA, M. (Org.) Memória e (res)sentimento: indagações sobre uma questão sensível. Campinas (SP): Ed. Unicamp, 2001. p.434, 436, 448; PRADO, 1999, p.181, 184.

${ }^{46}$ ALENCAR, Sonhos d'ouro, p.503-5, 507, 519-21, 575-6.

${ }^{47}$ Ibidem, p.531-2, 563.

${ }^{48}$ Ibidem, p.536, 567; PRADO, 1999, p.181.

${ }^{49}$ Ibidem, p.190; ALENCAR, Sonhos d'ouro, p.657. 